Eur. J. Clin. Chem. Clin. Biochem.

Vol. 32, 1994, pp. 461-463

(C) 1994 Walter de Gruyter \& Co.

Berlin - New York

\title{
Excretion of Free Catecholamines by Children
}

\author{
By C. Nuñez and M. A. Ortiz-Apodaca \\ Biochemistry Laboratory, Virgen de la Salud Hospital, Toledo, Spain
}

(Received September 24, 1993/February 21, 1994)

Summary: Excretion of free noradrenaline, adrenaline and dopamine were studied in random urine samples from 221 children (123 boys and 98 girls). The group was subdivided according to age, from birth to 12 years. The catecholamines were analysed by liquid chromatography with electrochemical detector using a $5 \mu \mathrm{m}$ C- 18 Novapack column at $32{ }^{\circ} \mathrm{C}$. The values were expressed per kilogram of creatinine. A statistical analysis (non-paired t-test) was carried out in order to define the different reference groups. Children under 2 years were found to have higher noradrenaline excretion than other ages; children under 4 years had higher adrenaline excretion than other ages. Children under 3 years had the highest dopamine excretion, followed by children between $3-6$ years, while children from 7 to 12 had the lowest excretion. Appropriate reference intervals were determined from the results.

\section{Introduction}

Neuroblastoma is the most common malignant tumour of the sympathetic nervous system in children (1). Such tumours are characterized by the production and increased secretion of dopamine, noradrenaline and adrenaline, and/or their acid metabolites vanillylmandelic acid and homovanillic acid. The diagnosis of neuroblastoma is based on the quantification of these compounds in urine. The great majority (75\%) of these tumours appear in children under 3 years of age and only a few (2\%) occur in patients older than 7 years (2). Several reference values for vanillylmandelic acid and homovanillic acid in children have been published $(3,4)$. However, only a few authors have reported reference values for urinary noradrenaline, adrenaline and dopamine. Data are sparse in particular for children under five years. On the other hand, as it is almost impossible to collect 24-hour urine samples from children, especially from those under 3 years of age, an attractive alternative is the use of single-void urine samples, relating excretion to urinary creatinine and expressing the results per kilogram of creatinine.

The purpose of the present study is to determine reference values for these compounds in their free form, expressed per kilogram of creatinine, in children from birth to 12 years.

\section{Materials and Methods}

\section{Sampling}

Random urine samples were taken from 221 healthy children (123 boys and 98 girls). The children's parents, who belong to the hospital staff, gave informed consent for this study. The study was approved by the biochemistry laboratory. Children were stratified by age, the youngest group covering the range from newborn to 1 year. The children avoided exposure to any agents known to alter catecholamine excretion (e. g. caffeinated beverages). We chose the time of urine collection at random, at any time in the day, to compensate the diurnal pattern of catecholamines and creatinine excretion.

Within less than 30 minutes, the $\mathrm{pH}$ of the urine samples was adjusted to $1-3$ by addition of $\mathrm{HCl} 6 \mathrm{~mol} / \mathrm{l}$. Acidified samples were then kept at $-20^{\circ} \mathrm{C}$ until analysis.

\section{Analysis of catecholamines}

Dopamine, noradrenaline and adrenaline were measured by liquid chromatography as described (5). The system included a model 510 pump, a Wisp 712 automatic injector, a M460 clectrochemical detector, a 740 data module and an oven with temperature control, all from Waters Chromatography Division, Millipore Co.

For the catecholamine separation, the oxidation-reduction power of the electrochemical detector was set at $600 \mathrm{mV}$. The flow rate of the mobile phase (sodium acetate $50 \mathrm{mmol} / \mathrm{l}$; citric acid $20 \mathrm{mmol} / \mathrm{l}$; 1-octane-sodium sulphate $3.75 \mathrm{mmol} / 1$; dibutylamine $1 \mathrm{mmol} / /$; disodium EDTA $0.135 \mathrm{mmol} / \mathrm{l}$ in HPLC grade water containing 50 $\mathrm{m} / \mathrm{ll}$ of methanol; final $\mathrm{pH} 4.3$ ) was $1 \mathrm{ml} / \mathrm{min}$. Separation was carried out using a $5 \mu \mathrm{m} \mathrm{C}-18$ Novapack (Waters) column at $32^{\circ} \mathrm{C}$.

$10 \mathrm{ml} \mathrm{Na} 2$ EDTA $2.7 \mathrm{mmol} / \mathrm{l}$ and $300 \mathrm{ng}$ 3,4-dihydroxybenzylamine as internal standard were added to $3 \mathrm{ml}$ urinc, and $\mathrm{pH}$ was 
adjusted to 6.5 with $\mathrm{NaOH} 0.5 \mathrm{~mol} / \mathrm{l}$. Catecholamines were retained in a Bio-Rex 70 ion exchange column (200 to 400 mesh, $\mathrm{Na}^{+}$) and afterwards washed with $15 \mathrm{ml}$ of HPLC grade water. The catecholamines were eluted with boric acid $0.65 \mathrm{~mol} / \mathrm{l}$. Subsequently $8 \mu \mathrm{l}$ of eluant was injected for quantification by HPLC.

The respective intra-assay coefficients of variation for noradrenaline, adrenaline and dopamine were $6.5 \%, 8.0 \%$ and $4,1 \%$; the respective inter-assay coefficients were $8.4 \%, 12.0 \%$ and $9.6 \%$. The percentage recovery of the catecholamines based on the recovery of internal standard in the urine was $95-100 \%$.

\section{Creatinine determination}

Creatinine was determined on a Hitachi 717 (Boehringer Mannheim, Mannheim, Germany) autoanalyser employing the modified Jaffé reaction.

\section{Statistical evaluation}

The mean value and standard deviation were calculated for each age group. The type of distribution was determined with the Kolmogorov-Smirnov test. In each age group, the values for catecholamines were tested for significant sex differences, using the non-paired t-test. In the absence of a significant sex-related difference males and females were subsequently treated as a single group. The non-paired t-test was also used to test for significant differences between age groups, and all groups showing no significant difference were combined.

\section{Results}

The mean value and standard deviation of the three catecholamines studied for each age group are shown in table 1.

The results show no significant differences due to sex. The Kolmogorov-Smirnov test showed a Gaussian distribution, in agreement with Parra et al. (6) and Reed et al. (7) but not with Fitzgibbon et al. (8).

The statistical evaluation revealed significant age-related differences in the excretion of free dopamine, noradrenaline and adrenaline. The noradrenaline excretion in children under 2 years is significantly $(p<0.001)$ higher than that in children of the other ages. Children under the age of 4 years excrete significantly $(p<0.001)$ higher levels of adrenaline than other ages. With respect to the dopamine excretion, the collective can be separated into three different age groups: newborn to 2 years, $3-6$ years, and $7-12$ years $(p<0.001)$. The age-related reference values based on these results are shown in table 2.

\section{Discussion}

The literature shows no general agreement on concentrations of free dopamine, noradrenaline and adrenaline in the urine of healthy children $(7-13)$. This is mainly because different age classifications are used. Furthermore, no author has tested for significant differences between catecholamine concentrations in different reference groups.

Although the comparison is difficult, our results are in general agreement with values published by Rosano (9), Abeling (12), Premel-Cabic et al. (10) and Muskiet et al. (11). However they are considerably lower than the results reported by Fitzgibbon et al. (8), a fact which the authors acknowledge in their paper (8). But when we test for significant differences between the reference groups, the results obtained surprised us; the new groups formed are not the same for the excretion of free noradrenaline, adrenaline and dopamine.

It is difficult to explain these findings. The sympathetic nervous system is immature at birth, and little information on its development over time exists. The stress of birth (14) gives rise to an increase in the levels of noradrenaline and adrenaline. Muskiet et al. (11) found that newborns excrete more normetanephrine and attri-

Tab. 1 Concentration of free catecholamines in urine of healthy children.

\begin{tabular}{|c|c|c|c|c|c|c|c|}
\hline \multirow[t]{2}{*}{$\begin{array}{l}\text { Age } \\
\text { (a) }\end{array}$} & \multirow[t]{2}{*}{$\mathrm{N}$} & \multicolumn{2}{|c|}{$\begin{array}{l}\text { Noradrenaline } \\
(\bar{x} \pm 2 \text { SD) }\end{array}$} & \multicolumn{2}{|c|}{$\begin{array}{l}\text { Adrenaline } \\
(\bar{x} \pm 2 \mathrm{SD})\end{array}$} & \multicolumn{2}{|l|}{$\begin{array}{l}\text { Dopamine } \\
(\bar{x} \pm 2 S D)\end{array}$} \\
\hline & & $\begin{array}{l}\mathrm{mg} / \mathrm{kg} \\
\text { creatinine }\end{array}$ & $\begin{array}{l}\mu \mathrm{mol} / \mathrm{mol} \\
\text { creatinine }\end{array}$ & $\begin{array}{l}\mathrm{mg} / \mathrm{kg} \\
\text { creatinine }\end{array}$ & $\begin{array}{l}\mu \mathrm{mol} / \mathrm{mol} \\
\text { creatinine }\end{array}$ & $\begin{array}{l}\mathrm{mg} / \mathrm{kg} \\
\text { creatinine }\end{array}$ & $\begin{array}{l}\mu \mathrm{mol} / \mathrm{mol} \\
\text { creatinine }\end{array}$ \\
\hline $0-1$ & 19 & $168 \pm 90$ & $112 \pm 60$ & $33 \pm 17$ & $20 \pm 10.5$ & $15 \dot{5} 4 \pm 89 \overline{5}$ & $1148 \pm 661$ \\
\hline 2 & 20 & $69 \pm 34$ & $46 \pm 23$ & $39 \pm 30$ & $24 \pm 20$ & $1012 \pm 612$ & $748 \pm 452$ \\
\hline 3 & 18 & $77 \pm 59$ & $51 \pm 39$ & $30 \pm 27$ & $18.5 \pm 16.7$ & $647 \pm 497$ & $478 \pm 367$ \\
\hline 4 & 20 & $55 \pm 33$ & $37 \pm 22$ & $38 \pm 49$ & $23 \pm 30$ & $598 \pm 211$ & $442 \pm 156$ \\
\hline 5 & 20 & $35 \pm 21$ & $23 \pm 14$ & $20 \pm 12$ & $12 \pm 7.4$ & $603 \pm 198$ & $445 \pm 146$ \\
\hline 6 & 20 & $51 \pm 17$ & $34 \pm 11$ & $16 \pm 10$ & $10 \pm 6.2$ & $598 \pm 263$ & $442 \pm 194$ \\
\hline 7 & 20 & $43 \pm 8$ & $29 \pm 5$ & $15 \pm 12$ & $9 \pm 7.4$ & $392 \pm 137$ & $290 \pm 109$ \\
\hline 8 & 18 & $32 \pm 28$ & $21 \pm 19$ & $9 \pm 5$ & $5.6 \pm 3.1$ & $501 \pm 148$ & $370 \pm 109$ \\
\hline 9 & 15 & $33 \pm 21$ & $22 \pm 14$ & $12 \pm 8$ & $7.4 \pm 4.94$ & $336 \pm 62$ & $248 \pm 458$ \\
\hline 10 & 17 & $54 \pm 54$ & $36 \pm 36$ & $15 \pm 13$ & $9 \pm 8$ & $405 \pm 171$ & $299 \pm 126$ \\
\hline 11 & 19 & $40 \pm 18$ & $27 \pm 12$ & $9 \pm 5$ & $6 \pm 3.1$ & $381 \pm 77$ & $281 \pm 57$ \\
\hline 12 & 15 & $45 \pm 28$ & $30 \pm 19$ & $12 \pm 10$ & $7.4 \pm 6.2$ & $.420 \pm 171$ & $310 \pm 126$ \\
\hline
\end{tabular}


Tab. 2 Reference values of catecholamines in single-void urine samples from children.

\begin{tabular}{|c|c|c|c|c|c|c|c|c|}
\hline \multirow[t]{2}{*}{$\begin{array}{l}\text { Age } \\
\text { (a) }\end{array}$} & \multicolumn{2}{|c|}{$\begin{array}{l}\text { Noradrenaline } \\
(\mathrm{x} \pm 2 \mathrm{SD})\end{array}$} & \multirow[t]{2}{*}{$\begin{array}{l}\text { Age } \\
\text { (a) }\end{array}$} & \multicolumn{2}{|c|}{$\begin{array}{l}\text { Adrenaline } \\
(\mathrm{x} \pm 2 \mathrm{SD}) \\
\end{array}$} & \multirow[t]{2}{*}{$\begin{array}{l}\text { Age } \\
\text { (a) }\end{array}$} & \multicolumn{2}{|l|}{$\begin{array}{l}\text { Dopamine } \\
(\mathrm{x} \pm 2 \mathrm{SD})\end{array}$} \\
\hline & $\begin{array}{l}\mathrm{mg} / \mathrm{kg} \\
\text { creatinine }\end{array}$ & $\begin{array}{l}\mu \mathrm{mol} / \mathrm{mol} \\
\text { creatinine }\end{array}$ & & $\begin{array}{l}\mathrm{mg} / \mathrm{kg} \\
\text { creatinine }\end{array}$ & $\begin{array}{l}\mu \mathrm{mol} / \mathrm{mol} \\
\text { creatinine }\end{array}$ & & $\begin{array}{l}\mathrm{mg} / \mathrm{kg} \\
\text { creatinine }\end{array}$ & $\begin{array}{l}\mu \mathrm{mol} / \mathrm{mol} \\
\text { creatinine }\end{array}$ \\
\hline $\begin{array}{l}0-1 \\
2-12\end{array}$ & $\begin{array}{r}168 \pm 90 \\
52 \pm 37\end{array}$ & $\begin{array}{r}112 \pm 60 \\
34 \pm 23\end{array}$ & $\begin{array}{l}0-3 \\
4-12\end{array}$ & $\begin{array}{l}37 \pm 31 \\
14 \pm 10\end{array}$ & $\begin{aligned} 22.8 & \pm 19 \\
8.6 & \pm 6.2\end{aligned}$ & $\begin{array}{l}0-2 \\
3-6 \\
7-12\end{array}$ & $\begin{array}{r}1244 \pm 751 \\
599 \pm 212 \\
408 \pm 139\end{array}$ & $\begin{array}{l}919 \pm 555 \\
442 \pm 157 \\
302 \pm 103\end{array}$ \\
\hline
\end{tabular}

buted this fact to an increased synthesis of noradrenaline at birth, even though a comparable increase could not be found for noradrenaline excretion. In an earlier unpublished study on the newborn, we also found no variation in catecholamine excretion during the first year of life. For this reason, we include 1 month-old and 1 yearold babies in the same group. In this case, statistically significant differences do exist when compared with those of other ages. Notterman et al. (15) found that the clearance of dopamine is age-dependent in children. Smaller children clear dopamine more quickly than older ones, this effect being more pronounced during the first months of life. It is possible that these facts could

\section{References}

1. Evans, A., d'Angio, G. \& Koop, C. (1976) Diagnosis and treatment of neuroblastoma. Symposium on Pediatric Oncology. Pediatr. Clin. North Am. 23, 161-170.

2. Knigh, J. A. \& Haymond, R. E. (1986) Catecholamine excretion by children: Work overlooked. Clin. Chem. 32, 2223-2228.

3. Tuchman, M. \& Stoeckeler, J. S. (1988) Conjugated versus "free" acidic metabolites of catecholamines in random urine samples: Significance for the diagnosis of neuroblastoma. Pediatr. Res. 23, 576-579.

4. Ito, S., Kato, T. Maruta, K., Jimbowe, K. \& Fujita, K. (1985) Total acidic metabolites of catecholamines in urine as determined by hydrolysis with hydriodic acid and liquid chromatography: Application to patients with neuroblastoma and melanoma. Clin. Chem. 31, 1185-1188.

5. Weicker, H., Feraudi, M., Hägele, H. \& Pluto, R. (1984) Electrochemical detection of catecholamines in urine and plasma after separation with HPLC. Clin. Chim. Acta 141, 17-25.

6. Parra, A., Ramirez del Angel, A., Cervantes, C. \& Sanchez, M. (1980) Urinary excretion of catecholaminès in healthy subjects in relation to body growth. Acta Endocrinol. 94, 546551.

7. Reed, P., Bu Lock, D., Jones, A. \& Layton, T. (1991) Reference ranges for free catecholamine/creatinine ratios in random urines from normal children aged 5 to 16 years. Ann. Clin. Biochem. 28, 297-298.

8. Fitzgibbon, M., Fitzgerald, R. J., Torney, W. P., O'Meara, A. \& Kenny, D. (1992) Reference values for urinary HMMA, HVA, noradrenaline, adrenaline and dopamine excretion in children using random urine samples and HPLC with electrochemical detection. Ann. Clin. Biochem. 29, 400-404. justify our reference values, although the mechanism responsible for this has yet to be elucidated.

From these results, we conclude that more information is required on the excretion of dopamine, noradrenaline and adrenaline. This could help in the study of endogenous catecholamines, and in the diagnosis and study of neuroblastoma in children.

\section{Acknowledgement}

The authors gratefully acknowledge the collaboration of Dr. Fernandez, head of the biochemistry laboratory, for all the facilities made available during this study, as well as the Automation Section of this laboratory for the help given in determining creatinine levels, and to Rosa $M^{a}$ Montaner for correcting the paper.

9. Rosano, T. G. (1984) Liquid-chromatographic evaluation of age-related changes in the urinary excretion of free catecholamines in pediatric patients. Clin. Chem. 30, 301-303.

10. Premel-Cabic, A., Turcant, A. \& Allain, P. (1986) Normal reference intervals for free catecholamines and their acid metabolites in 24-h urines from children, as determined by liquid chromatography with amperometric detection. Clin. Chem. 32, 1587-1587.

11. Muskiet, F. A. J., Thomason, C. G., Gerding, A. M., FremouwOttevangers, D. C., Nagel, G. T. \& Wolthers, B. G. (1979) Determination of catecholamines and their 3- $\alpha$-methylated metabolites in urine by mass fragmentography with use of deuterated internal standards. Clin. Chem. 25, 453-460.

12. Abeling, N. G., Van Gennip, A. H., Overmars, H. \& Voute, P. A. (1984) Simultaneous determination of catecholamines and metanephrines in urine by HPLC with fluorometric detection. Clin. Chim. Acta 137, 211-226.

13. Candito, M., Thyss, A., Albertini, M., Deville, A., Politano, S., Mariani, R. \& Chambon, P. (1992) Methylated catecholamine metabolites for diagnosis of neuroblastoma. Med. Pediatr. Oncol. 20, 215-2202.

14. Zaritsky, A. \& Chernow, B. (1984) Use of catecholamines in pediatrics. J. Pediatrics 105, 341-349.

15. Notterman, D. A., Greenwald, B. M., Moran, F. DiMaioHunter, A., Metakis, L. \& Reidenberg, M. M. (1990) Dopamine clearance in critically ill infants and children: Effect of age and organ system dysfunction. Clin. Pharmacol. Ther. $4 \delta$, 138-147.

Dra. M. A. Ortiz-Apodaca

Laboratorio de Bioquimica

Hospital Virgen de la Salud

Avda. Barber n. 30

E-45004 Toledo

Spain 
